\title{
TANTANGAN GURU DALAM PROSES PEMBELAJARAN DARING \\ DI MASA PANDEMI COVID-19
}

\author{
Aulia Annisa \\ E-mail: auliaannisa9902@gmail.com \\ *Program Studi Pendidikan Bahasa dan Sastra Indonesia, Universitas Riau
}

\section{Pengantar}

Sejak Februari 2020 yang lalu, Indonesia dan seluruh dunia digemparkan dengan merebaknya pandemi Covid-19. Berbagai aktivitas kehidupan manusia yang sebelumnya berlangsung normal harus berubah secara drastis dan signifikan mengikuti berbagai peraturan yang ditetapkan oleh Pemerintah guna mengurangi penyebaran virus corona ini. Semua kegiatan masyarakat harus dilakukan dan dilaksanakan dari rumah, seperti bekerja, bersekolah, beribadah, dan lainnya. Masyarakat diwajibkan mengikuti semua peraturan dan protokol kesehatan yang ditetapkan oleh Pemerintah dan Badan Kesehatan Dunia (WHO), dan harus menjalani kehidupan dengan tataran normal baru. Tentu saja hal ini mengubah segala aspek kehidupan manusia.

Begitu pula halnya di sektor pendidikan, pandemi ini juga mempengaruhi dan memberikan tantangan tersendiri bagi lembaga pendidikan di Indonesia. Pemerintah memutuskan untuk menutup sekolah dan juga perguruan tinggi. Pelaksanaan pembelajaran harus dirombak ulang dan disesuaikan guna beradaptasi mengikuti ketentuan protokol kesehatan yang melarang masyarakat untuk berkerumun di satu tempat yang ramai. Berbagai kebijakan pun disusun oleh pemerintah guna menanggulangi dampak virus ini terhadap proses belajar dan mengajar. Pembelajaran tatap muka (konvensional) ditiadakan, pembelajaran dilakukan di rumah melalui pembelajaran jarak jauh dan dengan menggunakan media online (Arizona dkk., 2020). Perubahan sistem belajar ini sontak saja membuat siapapun kaget dan harus memulainya tanpa ada kesiapan. Karena memang tidak ada siapapun yang siap dengan perubahan yang serba mendadak ini.

Hal ini tentu saja dirasa sangat berat oleh guru dan peserta didik. Terutama bagi guru, dimana guru dituntut harus bisa kreatif dan berinovasi dalam mengembangkan rencana pembelajaraan. Inovasi-inovasi yang diharapkan seperti dalam hal metode, media, dan sarana 
belajar agar tetap bisa mentransfer ilmunya kepada peserta didik meskipun dalam segala keterbatasan. Guru juga dituntut harus bisa menyesuaikan diri dengan berbagai teknologi dan aplikasi penyedia media pembelajaran. Guru-guru dituntut harus bisa melek teknologi dan menjalankan berbagai aplikasi guna tetap berlangsungnya proses belajar mengajar. Hal ini tentu saja menimbulkan tekanan fisik maupun mental bagi guru dan juga peserta didik. Dimana mereka dipaksa melakukan suatu hal yang baru dalam proses belajar mengajar.

Pembelajaran yang dilaksanakan secara daring juga memiliki beberapa kendala yang cenderung menghambat terlaksananya proses belajar dan mengajar dengan baik. Salah satunya ialah kendala jaringan dan akses internet. Dimana masih banyak daerah-daerah di Indonesia yang memiliki koneksi internet yang bisa dikatakan buruk. Ditambah lagi dengan keadaan ekonomi peserta didik yang menyebabkan mereka tidak memiliki ponsel ataupun laptop untuk menunjang terlaksanya pembelajaran yang semua aktivitasnya dilakukan secara daring. Tentu saja hal ini membutuhkan dukungan dan partisipasi para orang tua peserta didik agar bisa mendampingi dan memenuhi segala sarana dan prasarana peserta didik agar mereka tetap bisa mengikuti aktivitas pembelajaran yang dilaksanakan secara daring.

Solusi pembelajaran yang bisa dilakukan selama pandemi Covid-19 ini ialah guru harus bisa berinovasi dan menyesuaikan diri dengan berbagai perubahan dan teknologi yang ada, berpikir kreatif dan berkolaborasi dengan peserta didik dan orang tua peserta didik. Guru harus mengusahakan menerapkan model pembelajaran yang disesuaikan dengan keadaan dan kondisi para peserta didik. Dalam hal ini sangat dituntut kerja sama antara guru, peserta didik, dan orang tua peserta didik agar tetap bisa mencapai dan memenuhi tujuan kompetensi pendidikan yang telah ditetapkan.

\section{Guru}

Anggapan bahwa profesi seorang guru adalah sebuah profesi yang sangat mulia itu adalah benar adanya. Bagaimana tidak dikatakan demikian, dari tangan guru-guru hebat inilah yang nantinya juga akan menghasilkan generasi yang hebat pula. Orang-orang sukses, berhasil, dan berjaya dihasilkan dari jasa dan ilmu-ilmu yang ditransfer oleh para guru. Guru juga disebut sebagai pahlawan tanpa tanda jasa. Begitu banyak jasa yang ia lakukan untuk para muridnya, mulai dari mendidik, membimbing, mengarahkan, melatih, dan mengajari ilmu-ilmu yang ia punya dengan harapan bahwa murid-muridnya akan menjadi pribadi yang 
lebih berilmu. Mereka tidak pernah mengharapkan balasan berupa pangkat atau jabatan yang tinggi atas apa yang mereka lakukan, guru hanya berharap mereka bisa menjadi pelita yang akan menerangi bangsa ini dengan ilmu yang mereka punya. Namun, berprofesi sebagai seorang guru bukanlah suatu hal yang mudah. Seorang guru harus mengetahui bagaimana menjadi seorang guru yang baik, berkualitas, bertanggung jawab, dan bersikap profesional.

Zulfiati (2014) guru tidak hanya berperan sebagai penyampai materi pelajaran kepada peserta didik, tetapi juga berperan sebagai pendidik. Saifuddin (2014) guru memiliki peran dan fungsi beragam meliputi, guru sebagai sumber belajar, fasilitator, pengelola pembelajaran (learning manager), sebagai demonstrator, sebagai pembimbing, sebagai motivator, sebagai evaluator, dan guru sebagai mediator. Guru sebagai orang yang patut digugu dan ditiru dituntut agar bisa menjalankan peran dan fungsinya dengan baik, karena semua tindakan dan tingkah laku guru itulah yang akan menjadi contoh dan suri tauladan yang dilihat oleh peserta didik. Guru haruslah bisa mencontohkan dan menanamkan nilai-nilai dan norma luhur kepada para peserta didik, menciptakan suasana belajar yang nyaman, hangat dan kondusif. Dengan demikian akan tercipta proses belajar mengajar yang menyenangkan dan proses transformasi ilmu pengetahuan juga akan berlangsung dengan baik. Namun tentu saja setiap profesi memiliki kendala dan hambatan yang menghambatnya, sehingga guru harus bisa berpikir kreatif dan inovatif untuk bisa mencari solusi dari setiap permasalahan tersebut agar tujuan dari pendidikan tercapai, yakni untuk mencerdaskan kehidupan bangsa.

Untuk menjadi seorang guru haruslah memenuhi persyaratan sebagai manusia yang bertanggung jawab dalam pendidikan. Guru sebagai pendidik bertanggung jawab untuk mewariskan nilai-nilai dan norma-norma kepada generasi berikutnya sehingga terjadi konversi nilai, karena melalui proses pendidikan inilah diusahakan terciptanya nilai-nilai baru (Rukhayati, 2020). Untuk itu, menjadi seorang guru memanglah tugas yang mulia namun penuh perjuangan. Guru haruslah belajar dan terlebih dahulu sebelum akhirnya terjun untuk lapangan untuk mengajari peserta didik. Maka layaklah seorang guru dikatakan sebagai pelita dalam kegelapan. Guru membawa cahaya ilmu pengetahuan yang akan merubah seseorang. Guru juga menjadi penentu kualitas mutu pendidikan suatu bangsa (Zulhafizh, . Jika suatu bangsa maju dan berjaya, maka bisa dipastikan salah satu sebab hal itu terjadi ialah karena jasa dan pengorbanan para guru. 


\section{Pembelajaran Daring}

Pembelajaran daring atau pembelajaran dalam jaringan merupakan salah satu alternatif yang bisa dilakukan di masa pandemi Covid-19 ini. Dimana di masa pandemi ini Pemerintah mengeluarkan kebijakan agar masyarakat menghindari kerumunan dan tempattempat yang ramai, baik itu dalam hal bekerja, sekolah, beribadah, dan kegiatan-kegiatan lainny. Semuanya dilakukan dari rumah guna memutus rantai penyebaran virus Covid ini. Dalam dunia pendidikan kondisi ini mengubah tatanan cara belajar peserta didik dan pendidik, mereka harus memutar arah dari tradisional ke modern agar proses pembelajaran tetap berlangsung walaupun dalam kondisi pandemic Covid-19 (Zulhafizh, \& Silvia Permatasari, 2020). Sehingga cara yang dianggap paling efektif agar proses pembelajaran tetap bisa dijalankan dan tidak terganggu ialah dengan menerapkan pembelajaran secara daring dengan menggunakan media online. Alternatif dan keterpaksaan menjadi salah satu hakikat dari konsep pembelajaran daring ini. Sebenarnya, pembelajaran daring bukanlah suatu hal yang baru di dunia pendidikan. Konsep ini sudah ada sejak kemunculan mediamedia pembelajaran online seperti e-book, e-learning, e-laboratory, e-library, dan sebagainya. Namun penggunaan media ini bukan mutlak digunakan untuk proses pembelajaran, melainkan sebagai media bantu pembelajaran saja. Namun semenjak pandemi Covid-19 ini, penggunaan media daring bisa dikatakan mutlak digunakan demi terlaksananya proses belajar mengajar.

Pembelajaran daring dalam istilah akademik lebih dikenal dengan istilah pembelajaran online (online learning), atau istilah umum yaitu pembelajaran jarak jauh (learning distance). Pembelajaran daring merupakan pembelajaran yang berlangsung di dalam jaringan dimana pengajar dan yang diajar tidak bertatap muka secara langsung (Pohan, 2020). Menurut Bilfaqih dan Qomarudin (dalam Sulaeman, 2020) pembelajaran daring merupakan pelaksanaan kelas pembelajaran dalam jaringan untuk mencapai kelompok target yang utuh dan luas, sehingga pembelajaran daring ini dapat diselenggarakan dimana saja dan kapan saja dan dapat diikuti secara gratis maupun berbayar. Sedangkan menurut Meidawati (dalam Sulaeman, 2020) pembelajaran daring learning dapat dipahami sebagai pendidikan formal yang diselenggarakan oleh sekolah yang peserta didik dan instrukturnya (guru) berada di lokasi terpisah sehingga memerlukan system telekomunikasi interaktif untuk menghubungkan keduanya dan berbagai sumber daya yang diperlukan didalamnya. Jadi, Pembelajaran daring ini berlangsung di dalam jaringan dengan memanfaatkan jaringan 
internet dalam proses pembelajarannya, bisa dilakukan kapan saja dan di mana saja, meskipun berbeda-beda tempat dan lokasi dan tidak bertatap muka secara langsung.

Pohan (2020) pembelajaran daring di Indonesia diselenggarakan dengan aturan dan system yang terpusat pada peraturan yang ditetapkan oleh pemerintah. Untuk mengatur pembelajaran daring Pemerintah merumuskaan dasar-dasar hukum penyelenggaraan pembelajaran daring di masa pandemi Covid-19. Adapun dasar hukum yang dimaksud adalah:

a) Keppres No. 11 Tahun 2020, tentang Penetapan Kedaruratan Kesehatan Masyarakat Covid-19;

b) Keppres No. 12 Tahun 2020, tentang Penetapan Bencana Nonalam Penyebaran Corona Virus (Covid-19) Sebagai Bencana Nasional;

c) Surat Keputusan Kepala BNPB Nomor 9.A. Tahun 2020, tentang Penetapan Status Keadaan Tertentu Darurat Bencana Wabah Penyakit akibat Virus Corona di Indonesia;

d) SE Mendikbud No. 3 Tahun 2020, tentang Pencegahan Covid-19 pada Satuan Pendidikan;

e) Surat Mendikbud No. 46962/MPK.A/HK/2020, tentang Pembelajaran secara Daring dan Bekerja dari Rumah dalam rangka Pencegahan Penyebaran Covid19 pada Perguruan Tinggi;

f) SE Mendikbud No. 4 Tahun 2020, tentang Pelaksanaan Kebijakan Pendidikan dalam masa darurat penyebaran virus Corona;

g) Surat Edaran Menteri PANRB No. 19 Tahun 2020, tentang Penyesuaian Sistem Kerja Aparatur Sipil Negara dalam Upaya Pencegahan Penyebaran Covid-19 di Lingkungan Instansi Pemerintah.

Dalam pembelajaran daring ini guru tidak dibatasi oleh aturan ataupun batasan dalam memilih dan menggunakan media pembelajaran online mana yang akan guru gunakan. Hal ini berarti bahwa guru bebas menggunakan media apa saja yang dianggap bisa digunakan untuk berkomunikasi dengan baik dengan para peserta didik. Beberapa platform atau media online yang dapat digunakan oleh guru dalam proses pembelajaran daring antara lain seperti Google Meet, Google Class Room, Zoom, e-mail, E-Learning, Edmodo, WhatsApp, dan sebagainya. 


\section{Tantangan Guru dalam Pembelajaran Daring}

Seperti yang kita tahu bahwa pembelajaran daring merupakan pembelajaran yang memanfaatkan jaringan internet dalam proses pembelajarannya, dan kecakapan seseorang dalam menguasai dan menjalankan teknologi juga menentukan kelancaran pembelajaran. Pembelajaran dalam jaringan sampai saat ini masih dianggap sebagai pro kontra. Ada yang merasa bahwa sistem pembelajaran ini lebih efektif dan efisien digunakan, dan ada juga yang merasa kewalahan dan mengganggap pembelajaran secara daring ini susah. Terutama bagi para guru. Guru memegang peranan penting pada pembelajaran daring ini, dimana guru merupakan orang yang mengkoordinir jalannya pembelajaran.

Di masa pandemi ini guru memiliki tantangan tersendiri. Guru harus menjalankan peran ganda yakni sebagai penggerak dan pembina yang memiliki kemampuan luar biasa untuk melakukan pembelajaran jarak jauh. Di masa pandemi ini guru dituntut untuk melaksanakan berbagai tugas tambahan guna memastikan tercapainya tujuan pendidikan dan pemenuhan target akademis serta non-akademis. Selain itu guru juga dituntut untuk bisa berinovasi dan menemukan ide-ide materi pelajaran, metode, cara, media, dan lainnya agar pembelajaran tetap bisa berlangsung menyenangkan bagi para peserta didik walaupun harus dibatasi oleh jarak.

Tantangan pertama yang harus dihadapi oleh guru dalam pembelajaran daring ialah harus melek teknologi, guru harus menguasai tata cara penggunaan teknologi penunjang pembelajaran. Teknologi merupakan hal yang terpenting dalam pembelajaran daring, teknologi tersebut diantaranya dapat berupa smartphone, laptop dan benda pendukung lainnya. Smartphone/gadget adalah hal yang paling umum digunakan oleh peserta didik dari pada laptop, karena lebih praktis dan banyak fitur canggihnya (Subiyakto, dkk., 2019). Anggap saja pembelajaran daring ini bisa dilakukan oleh guru-guru yang masih muda dan mahir dengan teknologi, maka lain halnya dengan guru-guru yang masih meraba dalam penggunaan teknologi. Terutama bagi guru-guru yang berada di daerah-daerah dan lanjut usia, sedikit dari mereka yang mahir menggunakan perangkat komputer dan mengelola aplikasi pengajaran. Pada umumnya mereka hanya mampu mengoperasikan perangkat komputer sebatas untuk keperluan mengetik dengan $M S$ Word, itupun banyak yang tidak paham semua fasilitas yang ada di program itu, apalagi menjalankan e-mail, Browsing Web, dan sebagainya. Namun di masa pandemi dan pembelajaran daring guru dituntut harus bisa mengoperasikan perangkat komputer, laptop maupun gawai, menjalankan aplikasi 
pembelajaran, membuat materi pembelajaran yang menarik, memanfaatkan bermacam digital tools, menyelenggarakan kelas secara online, serta menyiapkan administrasi secara online. Tentu saja ini menjadi tantangan tersendiri serta pengalaman belajar hal yang baru bagi guru.

Kedua, kendala jaringan internet. Hal yang juga menjadi tantangan bagi guru di pembelajaran daring ini ialah masalah internet. Diantaranya, akses jaringan internet yang susah terutama di daerah pedesaan, jaringan internet yang tidak stabil. Akibat jaringan yang lamban, informasi dan materi pembelajaran yang disampaikan memerlukan waktu yang cukup lama untuk diterima oleh siswa, ataupun sebaliknya (Arifah Prima Satrianingrum dan Iis Prasetyo, 2021). Kecepatan akses internet belum bisa dirasakan oleh seluruh daerah di Indonesia. Daerah-daerah terpencil, pedalaman, dan pelosok masih belum bisa menikmati kualitas jaringan internet. Hal ini akhirnya berimbas kepada guru dan pelaksanaan pembelajaran daring yang semua aktivitasnya menggunakan jaringan internet.

Ketiga, sarana pendukung pembelajaran siswa kurang memadai. Menurut Arifah Prima Satrianingrum dan Iis Prasetyo (2021) dalam pelaksanaan pembelajaran secara daring, salah satu keterbatasan dalam pelaksanaannya ialah sarana dan prasarana yang tidak mendukung, seperti laptop, komputer, smartphone, kuota internet dan lain sebagainya. Sarana prasarana menjadi begitu penting dalam mengakomodasi pelaksanaan pembelajaran bagi siswa. Menurut M. Wahyudi (2020) fakta di lapangan, kewajiban belajar di rumah menjadi kendala serius khususnya bagi peserta didik dari kalangan yang kurang beruntung secara ekonomi. Hal ini secara tidak langsung juga menjadi tantangan bagi guru, karena guru harus mencari cara agar peserta didik yang tidak memiliki sarana pembelajaran seperti smartphone atau laptop tetap bisa mengikuti pembelajaran. Salah satunya yaitu dengan cara memperbolehkan peserta didik tersebut untuk ke sekolah agar tetap bisa menerima materi yang diajarkan. Kesiapan infrastruktur sekolah, kesediaan sarana smartphone juga menjadi masalah yang harus dihadapi di pembelajaran daring ini.

Memang tidak mudah bagi guru untuk melakukan aktivitas pembelajaran saat masa pandemi Covid-19 ini. Guru harus bisa menyesuaikan diri dengan segala perubahan dan tuntutan yang ada. Meskipun pembelajaran daring ini adalah pengalaman baru yang dipenuhi ketidakpahaman, diwarnai oleh beberapa tantangan dan hambatan, namun yang namanya guru tetaplah guru. Mereka harus tetap memenuhi kewajibannya sebagai seorang tenaga pendidik dan penyalur ilmu. Segala tantangan yang dihadapi harus bisa dijadikan sebagai pelajaran dan pengalaman berharga untuk tetap bisa berbagi pengetahuan kepada para siswa. 
Meskipun peran guru di tengah pandemi ini jarang disebut sebagai garda terdepan dalam melawan Covid-19, namun guru merupakan pahlawan pembangunan pengetahuan bangsa.

\section{Penutup}

Pandemi Covid-19 telah mengubah tatanan kehidupan manusia. Perubahan ini juga mempengaruhi dan memberikan tantangan tersendiri bagi lembaga pendidikan di Indonesia. sistem pembelajaran tatap muka yang dilaksanakan terpaksa harus berubah menjadi sistem pembelajaran dalam jaringan atau tanpa tataap muka. Tentu saja perubahan pembelajaran ini mengagetkan semua pihak, baik itu sekolah, guru, peserta didik, maupun orang tua peserta didik. Sistem pembelajaran harus dilakukan dengan cara meraba-raba untuk menentukan pembelajaran yang cocok yang sesuai dengan situasi dan kondisi guru dan peserta didik. Tentu saja di dalam proses yang serba mendadak tanpa adanya persiapan ini harus menghadapi berbagai masalah dan tantangan. Namun semua pihak harus bisa bekerja sama dan mencari solusi agar pembelajaran tetap bisa terlaksana dan proses transfer ilmu tidak terhenti oleh situasi pandemi ini. Dan dalam kondisi pandemi ini, salah satu pihak yang harus diberi acungan jempol ialah guru. Dimana dengan segala keterbatasan dan kegagapan dalam menjalankan teknologi, guru tetap menjalankan tanggung jawab dan kewajibannya untuk berinovasi dan menciptakan suasana belajar yang sesuai dan menyenangkan.

\section{Referensi}

Arizona, K., Abidin, Z., \& Rumansyah, R. (2020). Pembelajaran Online Berbasis Proyek Salah Satu Solusi Kegiatan Belajar Mengajar di Tengah Pandemi Covid-19. Jurnal Ilmiah Profesi Pendidikan, 5 (1), 64-70.

Pohan, Albert Efendi. 2020. Konsep Pembelajaran Daring Berbasis Penddekatan Ilmiah. CV Sarnu Untung: Jawa Tengah.

Rukhayati, Siti. 2020. Strategi Guru PAI dalam Membina Karakter Peserta Didik SMK AlFalah Salatiga. Lembaga Penelitian dan Pengabdian Kepada Masyarakat (LP2M): Salatiga.

Saifuddin. 2014. Pengelolaan Pembelajaran Teoritis dan Praktis. Deepublish Publisher: Yogyakarta. 
Satrianingrum, Arifah Prima, \& Iis Prasetyo. (2021). Persepsi Guru Dampak Pandemi Covid19 terhadap Pelaksanaan Pembelajaran Daring di PAUD. Jurnal Obsesi: Jurnal Pendidikan Anak Usia Dini, 5 (1), 633-640.

Subiyakto, B., Susanto, H., \& Akmal, H. (2019). Media Pembelajaran Sejarah Era Teknologi Informasi. Banjarmasin: Program Studi Pendidikan Sejarah, ULM.

Sulaeman, Asep. 2020. Pemberdayaan Masyarakat di Era New Normal Pandemi Covid-19. UIN Sunan Gunung Djati: Bandung.

Wahyudi, M. (2020). Imbas Pandemi Virus Corona bagi Dunia Pendidikan Indonesia dan Global. Kumparan.

Zulfiati, Heri Maria. (2014). Peran dan Fungsi Guru Sekolah Dasar dalam Memajukan Dunia Pendidikan. Jurnal Pendidikan Ke-SD-an, 1 (1), September, 1-4.

Zulhafizh, \& Silvia Permatasari. Membina Kualitas Belajar di Masa Pandemi Covid-19 Masa Pandemi Covid-19 Melalui Sikap Berpikir Kreatif danKritis. Jurnal Pendidikan dan Pengajaran, 4 (5), 937-949.

\section{*Data Penulis}

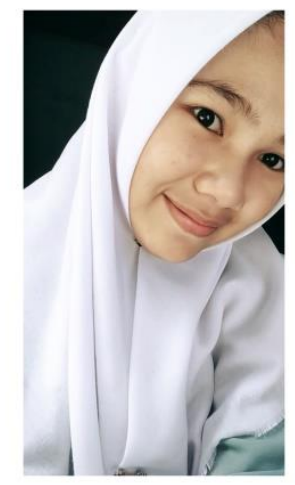

Aulia Annisa, lahir di Padang Tarap, 02 Oktober 1999. Pada tahun 2018, ia menamatkan pendidikan Sekolah Menengah Atas di SMAN 1 Kampar Utara. Dan pada tahun itu juga ia melanjutkan pendidikan strata satu di Jurusan Bahasa dan Seni Program Studi Pendidikan Bahasa dan Sastra Indonesia FKIP Universitas Riau melalui jalur SBMPTN (Seleksi Bersama Masuk Perguruan Tinggi Negeri).

Beberapa karyanya berhasil diterbitkan menjadi sebuah buku, diantaranya Tinta (Antologi Puisi), 7 Seuntai (Antologi Puisi Septima), Prasasti Usang (Antologi Cerpen), dan Panca Rona (Antologi Fabel). Buku-buku ini ia terbitkan bersama teman-teman mahasiswa Program Studi Pendidikan Bahasa dan Sastra Indonesia kelas 2018 B dan 2018 A.

Kontak :

Hp/WA : +6282284555983

E-mail : auliaannisa9902@gmail.com; aulia.annisa2852@student.unri.ac.id 